\title{
Damage impact of vertebrate pests on different crops and stored food items
}

\author{
Qamar Safi Ur Rehman *, Khan Waqar Ali, Wasti Syed Muhammad Ali, Majeed Waqar, Naveed Muhammad, \\ Samad Abdul and Khan Aziz Ullah \\ Department of Zoology, Wildlife, and Fisheries, Faculty of Science, University of Agriculture Faisalabad, Faisalabad 38000, \\ Punjab-Pakistan.
}

Publication history: Received on 18 December 2018; revised on 10 January 2019; accepted on 15 January 2019

Article DOI: https://doi.org/10.30574/gscbps.2019.6.1.0162

\begin{abstract}
The sub-continent countries like Pakistan, India, and Bangladesh that fall in the category of developing countries suffer from high economic loss due to the damage to valuable crops. The crops are always under attack by vertebrate pests including rodent and bird pests during the time period of harvesting and storage. Our current study indicates that most of the crop damage and economic loss were caused by rodent pests. Vertebrate rodent pests include Mus musculus (house mouse) and Bandicota bengalensis (lesser bandicoot rat), Rattus norvegicus and Rattus rattus caused damage to crops like sugarcane, maize, household stored food items and grains. On contrary, the major bird pest is Psittacula Krameri (Rose Ringed Parakeet) that caused damage to fruit gardens of Common Fig (Anjeer) and parrots, Guava and Cascabela thevetia (Pilli Kaneri). Rodents damage the seeds, standing crop and food items stored in households. While birds always prefer fresh fruits from the tree. The methodology of the study simply consists of the surveying of the different field of sugarcane, maize, fruit gardens of different villages in district Faisalabad and also includes different research gardens at main campus UAF. After collection, the samples were critically studied for pest identification in the laboratory at the department of zoology, wildlife and Fisheries University of Agriculture Faisalabad. The results demonstrated that both rodent pests and bird pest are equally depredatory towards valuable crops. In order to reduce this loss, we have to bring about the advances in the vertebrate pest management like the use of pesticides (Chemical) and some mechanical methods for trapping, killing and pushing of vertebrate pests.
\end{abstract}

Keywords: Vertebrate; Damage; Rodent; Birds; Pest; Crops; Stored food

\section{Introduction}

In developing, countries crops and stored food are highly aimed at damage by different vertebrate pests. Specified information on food and crop yield loss in developing counties is not documented as required. The people of developing countries loss their stored food and crops containing economical yield due to the attack of rats, mice and pest birds [12]. These problems are not described properly by researchers and agriculturists. Damage due to vertebrate pest's farmers bears the double loss, during harvesting season and post-harvest [3-4]. Most of the crops are vulnerable to vertebrate pests during its growth stages and stored food is vulnerable for as long as they are held in storage [5-7].

Commonly after harvesting the crop yield is stored in farmhouses in specialized structures that are designed especially for storage. These structures are present in the territory of one or more species of vertebrate pests including indigenous rodents and possibly depredatory birds [8]. Stored food is lost due to time to time consumption, contamination, wastage, and spoiled by vertebrate pests [9]. This is the first step towards next crop yield loss due to damaged seeds which are required by the farmer for plantation of the particular crop during its harvesting season [10].

\footnotetext{
${ }^{*}$ Corresponding author

E-mail address: ranasafi73@gmail.com
} 
The negative impact of vertebrate pests on agriculture by eating and damaging crops lead to loss of agricultural yield as well as loss in economy. Damage impacted by rodents and depredatory birds can be harsh, may vary according to geography and season. Farmers apply many techniques to overcome economic loss due to rodents and birds by using rodenticides, avicides, trapping and aversion [11]. Although these strategies are effective at limiting crop loss, damage due to rodents and birds remains a problem in developing countries. Research on damage due to rodent and bird pests outlies the detail related to single or multiple species impacting only one crop's final product [12-14] or one species having an impact on different crop's final product [15]. There is a small portion of research which actually show detail on multiple pest species damages to multiple crops [16].

This study points out the major vertebrate pests of different crops and highlights the damage profile of these vertebrate pests on different crops including sugarcane, maize, and stored food items which include biscuits, chocolates, dates, stored seed of different crops and stored grains. During the study of vertebrate pest and their damage profile, we found out the major rodent pests are Mus musculus (house mouse) and Bandicota bengalensis (lesser bandicoot rat), while the major bird pest is Psittacula Krameri (rose-ringed parakeet).

\section{Material and methods}

\subsection{The material of study}

The study material includes crops of sugarcane, maize, root tuber, guava, common fig, and Cascabela thevetia. While stored food items include biscuits, dates, seeds of maize and chocolates.

\subsection{Area of study}

We started our study by visiting the fields and storehouses of fruits, grains, vegetables in our selected study areas. We selected 204 R.B village, 208 R.B village, 209 R.B village, University of Agriculture Faisalabad's research gardens and warehouses of Faisalabad District in the grain market (Figure 1). Out of these areas, 204 R.B village, 208 R.B village and 209 R.B village is famous to produce quality maize and sugarcane. In the University of Agriculture Faisalabad (UAF) Research Gardens different plants of Common Fig (Anjeer), Guava and Cascabela thevetia (Pilli Kaneri) are produced for research purpose. While in grain market we found plenty of grains, seeds of different crops and ground nuts in storehouses. Therefore we selected these areas for the study of vertebrate pests including rodents and birds. This study includes the information collected through samples. Different techniques, pesticides, and mechanical methods are used by farmers to overcome the damage of vertebrate pests on the crops of sugarcane and maize. While in grain market the shopkeepers use mechanical methods to overcome the damage due to rodents.

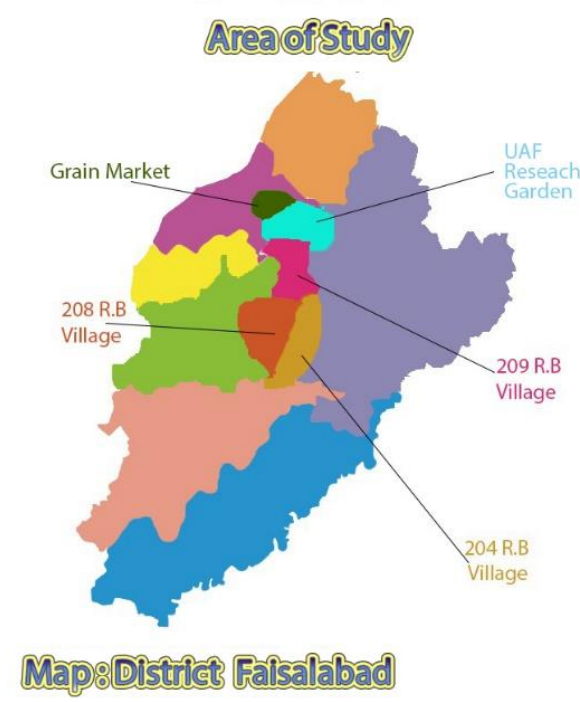

Figure 1 Map of study area

\subsection{Collection of samples}

An idiosyncratic sampling technique is used to collect samples from different fields of sugarcane, maize, research gardens of guava and olive by scrutinizing the fruits of these crops conscientiously. We collected most of the samples 
from 208 R.B village, 209 R.B village, UAF research garden and grain market. After collection, samples were brought in the laboratory of Department of Zoology, wildlife and fisheries, the University of Agriculture Faisalabad for the identification of pests that damage the particular crop, seed, and food item by expert pest manager.

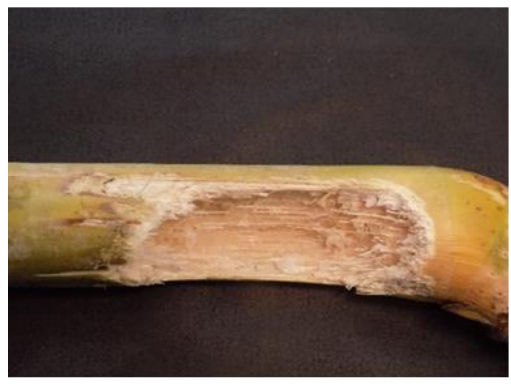

A

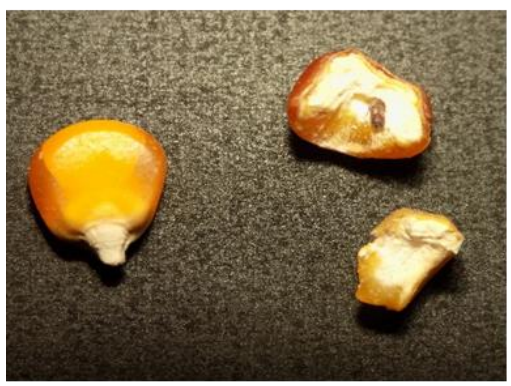

D

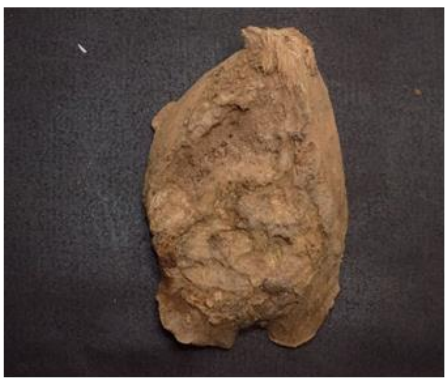

B

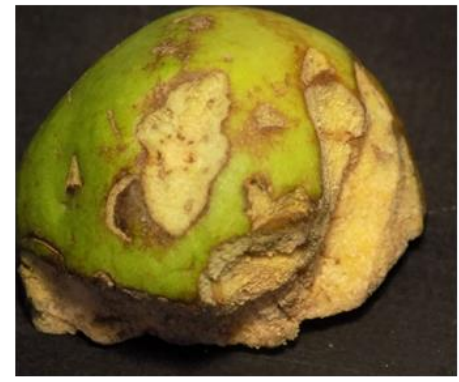

$\mathrm{E}$

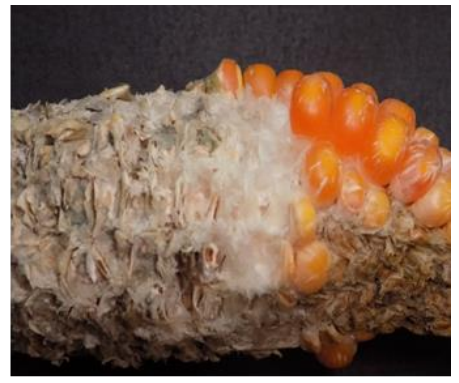

C

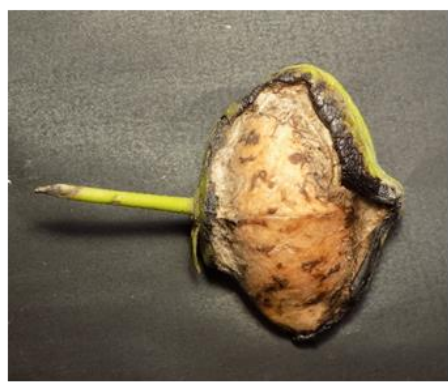

$\mathrm{F}$

Figure 2 Samples used for the study. A- Sugarcane damaged by B. bengalensis, B- Root tuber damaged by $B$. bengalensis, C- Maize kernal damaged by B. bengalensis, D- Maize seeds damaged by M. musculus, E-Guava damaged by P. Krameri and F- C. thevetia damaged by Psittacula Krameri

\section{Results and discussion}

Samples of damaged crops and stored food items were collected from the study area during the harvesting and postharvest season. We identified two major rodent pests and one bird pest, causing significant damage to valuable crops during harvesting season and post-harvest in warehouses. These pests are Mus musculus (house mouse), Bandicota bengalensis (lesser bandicoot rat) and Psittacula Krameri (rose-ringed parakeet). These vertebrate pests affect crop in various ways. These pests damage major parts of crops during harvesting season and post-harvest, which results in a heavy economic loss.

This study provides significant knowledge about the damaging impact of the vertebrate pest on sugarcane, maize, root tubers crops and on stored food items. Sugarcane, maize and root tuber are attacked by vertebrate pests during their mature stage because at the mature stage the nutritional content is quite high which helps them to fulfill their requirements. Stored food items came under attack when it is stored in that warehouses which are near to the habitat of rodent pest. According to the report of Madhusudan (2003), about 11\% economic loss is due to the damage of crops during the post-harvest time [17]. Crop damaged by rodents and bird pests is a common thing in the district Faisalabad. The loss during the post-harvesting season can be overcome by storing items at clean and pest proof premises. Most of the Pesticides inhibit the population of rodent and bird pests; however, crop production is variable across time and space [11]. Integrated pest management proved to be a more effective technique in reducing pest damage and increasing yield of the particular crop [18].

During the study, we noticed that the pest activities are enormously higher during crop's mature state and its rate doubles after post harvesting situation. Damage at the earlier stage or mature stage results in low crop production as well as greater economic loss. The geographical conditions of study areas favor the survival of vertebrate pest. Due to geographical and climatic conditions of crop cultivated areas i.e. 204 village, 208 village and 209 village, it is favorable for the growth and reproduction of non-identical rodent pest especially Bandicota bengalensis (lesser bandicoot rat) and Mus musculus (house mouse). While UAF research gardens and grain market favor the vertebrate bird pest Psittacula krameri (rose-ringed parakeet) and rodent pest Mus musculus (house mouse) respectively. The damaging 
impact of vertebrate pests can be controlled by proper monitoring principally during the maturation spell of crops and during post-harvest. Farmers use pesticides and mechanical methods to reduce the economic loss caused by vertebrate pests. The recorded observations are mentioned in Table 1.

Table 1 Observed vertebrate pest and their damage to the crop and stored food items

\begin{tabular}{|c|c|c|}
\hline Crop/Food item & Pest observed & Damage \\
\hline Sugarcane & \multirow{3}{*}{$\begin{array}{l}\text { Bandicota bengalensis } \\
\text { (lesser bandicoot rat) }\end{array}$} & $\begin{array}{l}\text { Lesser bandicoot rat eats the stem of sugarcane from } \\
\text { nodes and internodes. Specially internode which } \\
\text { contains higher contents of glucose (Figure } 2 \mathrm{~A} \text { ). }\end{array}$ \\
\hline Maize & & $\begin{array}{l}\text { Lesser bandicoot rat eats mostly the kernel of maize } \\
\text { (Figure 2C). }\end{array}$ \\
\hline Root tuber & & $\begin{array}{l}\text { Lesser bandicoot rat eats the upper part of root tuber } \\
\text { and left the rest with its damage signs (Figure 2B). }\end{array}$ \\
\hline Stored biscuits & \multirow{3}{*}{$\begin{array}{l}\text { Mus musculus } \\
\text { (house mouse) }\end{array}$} & $\begin{array}{l}\text { House mouse damage the biscuits in a unique pattern } \\
\text { by eating it smoothly and form curve like pattern. }\end{array}$ \\
\hline Stored seeds of maize & & $\begin{array}{l}\text { Most of the seeds are damaged partially by the house } \\
\text { mouse (Figure 2D). }\end{array}$ \\
\hline Stored chocolate & & $\begin{array}{l}\text { Small packs of chocolate are damaged in a unique } \\
\text { manner that the teeth marks of house mouse are left on } \\
\text { the item. }\end{array}$ \\
\hline Guava & \multirow{3}{*}{$\begin{array}{l}\text { Psittacula krameria } \\
\text { (rose-ringed parakeet) }\end{array}$} & $\begin{array}{l}\text { Rose-ringed parakeet damages the guava fruit by } \\
\text { eating it from different sides and leave its damage } \\
\text { pattern on fruit (Figure 2E). }\end{array}$ \\
\hline Common fig & & $\begin{array}{l}\text { Rose-ringed parakeet damages the final product of } \\
\text { common fig by eating from the upper portion of the } \\
\text { fruit. }\end{array}$ \\
\hline Cascabela thevetia & & $\begin{array}{l}\text { Rose-ringed parakeet damages the whole fruit of } \\
\text { Cascabela thevetia and left only the seed (Figure } 2 \mathrm{~F} \text { ). }\end{array}$ \\
\hline
\end{tabular}

\section{Conclusion}

It is evident that most of the damage was due to rodents which occurred during the postharvest season. While bird pests always preferred fresh food by directly attacking plants. This loss can be compensated by using different management techniques. Rodent control strategies must consider economics as well as ecology. The differences in species composition of rodents depending on locality, habitat type, and preferred food. The high population density of rodents occurred in spring was increased activity. However, the lowest density was during the winter season. Baits of different colors may be used to control rodent's pests. Availability of food, Locality and neighboring are the key to control the pest. Mechanical, biological and chemical control methods can be used effectively in an Integrated Pest Management Approach (IPMA) for the regulation of the rodent's population density.

\section{Compliance with ethical standards}

\section{Acknowledgments}

We thank Dr. Hammad Ahmad Khan from Department of Zoology, Wildlife, and Fisheries, University of Agriculture Faisalabad and Dr. Farooq Ahmad from Department of Agriculture Entomology, University of Agriculture Faisalabad for helping us to identify the pest. Furthermore, all the authors contributed equally in this work.

\section{Disclosure of conflict of interest}

There is no conflict of interest among all authors. 


\section{References}

[1] Tobin ME and Michael WF. (2004). Pest control: Rodents. USDA, National Wildlife Research Center - Staff Publications, 67.

[2] Kumar D and Kalita P. (2017). Reducing postharvest losses during storage of grain crops to strengthen food security in developing countries. Foods, 6(1), 8.

[3] Gary WW. (2007). The ecology of vertebrate pests and integrated pest management (IPM). USDA National Wildlife Research Center - Staff Publications, 730.

[4] Bayani A, Tiwade D, Dongre A, Dongre AP, Phatak R and Watve M. (2016). Assessment of crop damage by protected wild mammalian herbivores on the western boundary of Tadoba-Andhari Tiger Reserve (TATR), Central India. PLOS ONE, 11(4), e0153854.

[5] Bhattarai BP and Basnet K. (2004). Assessment of crop damage by wild ungulates in the eastern side of Barandabhar corridor forest, Chitwan. Proceedings of IV National Conference on Science and Technology, 19761980.

[6] Bailey PT. (2007). Pests of field crops and pastures: identification and control. CSIRO Publishing, Clayton, Australia, 420-450.

[7] Gadi VPR. (2017). Integrated management of insect pests on canola and other brassica oilseed crops. Centre for Agriculture and Bioscience International, Wallingford, Oxford shire, United Kingdom, 240-255.

[8] Sridhara S. (2016). Vertebrate pests in agriculture. Scientific Publisher, Jodhpur, India, 378.

[9] Sridhara S. (2016). Vertebrate pests in agriculture. Scientific Publisher, Jodhpur, India, 455.

[10] Cerda R, Avelino J, Gary C, Tixier P, Lechevallier E and Allinne C. (2017). Primary and secondary yield losses caused by pests and diseases: assessment and modeling in Coffee. PLOS ONE, 12(1), e0169133.

[11] Sexton SE, Lei $Z$ and Zilberman D. (2007). The economics of pesticides and pest control. International Review of Environmental and Resource Economics, 1(3), 271-326.

[12] Cummings JL, Shwiff SA and Tupper SK. (2005). Economic impacts of blackbird damage to the rice industry. Pro. Wildl. Damage Manag. Conf, 11, 317e322.

[13] Berge A, Delwiche M, Gorenzel WP and Salmon T. (2007). Bird control in vineyards using alarm and distress calls. American journal of enology and viticulture, 58(1), 135-143.

[14] Delwiche MJ, Houk A, Gorenzel WP and Salmon TP. (2007). Control of crows in almonds by broadcast distress calls. Transactions of the ASABE, 50(2), 675-682.

[15] Marsh RE. (1998). Historical review of ground squirrel crop damage in California. International Biodeterioration and Biodegradation, 42(2-3), 93-99.

[16] National Agricultural Statistics Service (NASS). (2002). U.S. Wildlife Damage. Agricultural Statistics Board. U.S. Department of Agriculture.

[17] Madhusudan MD. (2003). Living amidst large wildlife: livestock and crop depredation by large mammals in the interior villages of Bhadra Tiger Reserve, South India. Environmental Management, 31(4), 466-475.

[18] Zilberman D, Schmitz A, Casterline G, Lichtenberg E and Siebert JB. (1991). The economics of pesticides use and regulation. Science, 253(5019), 518-522.

\section{How to cite this article}

Qamar SUR, Khan WA, Wasti SMA, Majeed W, Naveed M, Samad A and Khan AU. (2019). Damage impact of vertebrate pests on different crops and stored food items. GSC Biological and Pharmaceutical Sciences, 6(1), 16-20. 